\title{
ASSESSEMENT OF BEACH QUALITY IN THE NORTHEASTERN COAST OF VIETNAM BY USING INDEX METHOD
}

\author{
Do Thi Thu Huong ${ }^{1 *}$, Nguyen Dinh Hoe ${ }^{2}$, Tran Dinh Lan ${ }^{1}$, \\ Nguyen Thi Thu Ha ${ }^{1}$, Nguyen Dac Ve ${ }^{1}$ \\ ${ }^{1}$ Institute of Marine Environment and Resources, VAST \\ ${ }^{2}$ Hanoi University of Science, $V N U$ \\ *E-mail: huongdt@imer.ac.vn
}

Received: 21-6-2017

\begin{abstract}
This article assessed the quality of beaches in the northeastern coastal area of Vietnam via the Beach Quality Index (BQI) which is popularly applied in many countries. The BQI is combined from beach functional indices about recreation, ecology, and protection. The BQI was applied in 9 sandy beaches in the study area. The results show that most of the sandy beaches in the study obtain medium or high-quality level with the BQI score ranging from 0.56 to 0.71 except Do Son beach $(\mathrm{BQI}=0.36)$. In addition, assessment of sub-index and indicators could identify weak aspects of the beach which are used as a foundation for utilization orientation in order to enhance the beach quality as well as sustainable use of resources.
\end{abstract}

Key words: Sandy beach, beach quality index, northeastern coastal area in Vietnam.

\section{INTRODUCTION}

Marine tourism is one of the most developed business in coastal countries since it is considered a smokeless industry and a huge benefit brought to their economy. In which, sandy beaches are significant resources due to its valuable contribution to the tourism destination [1, 2]. The attraction of sandy beaches fosters marine tourism market and in the near future, there in the comparison not only about the charm of the landscape but also about the level of sustainable use of natural resources, culture and economy among the tourism destinations [3]. Recently, there are a lot of signals of environmental degradation, the negative effect on the ecosystem and tourism experiences resulted from those activities and tourism has converted effect to the people [4]. This situation happened in South Korea in 2011 when there was a huge amount of litter pushed up to the beaches in Geoje, and it caused a reduction of $63 \%$ of total tourists in comparison to a year before and as a result, the turnover dropped 29-37 million USD [5]. Moreover, the traditional exploitation of the beach aimed to serve the socio-economic development and ignored their ecological aspects. Those led to an unsuitable usage of sandy beaches in terms of their formation and environmental structural features [6]. Therefore, many environmental issues generated, for instance, beach erosion, bathing water pollution, landscape destruction... To mitigate these problems, the management of beach environment needs to identify all factors affecting them and since then find the way to improve their quality. An effective approach to management of beach environment is establishing a set of indicators, index or criteria for beach [7-9]. Many sets of indicators were established and widely applied for beaches such as Blue Flag, Blue Wave, 
Seaside Award [6, 10]. Those research results show that the development of criteria including the feature of the environment and morphology of the beach is very important in maintenance and management of beach quality.

The Northeastern coast of Vietnam with nearly 200 sandy beaches distributed mainly along islands in Ha Long bay, Cat Ba and Bai $\mathrm{Tu}$ Long archipelago is being an attractive tourism destination [11]. However, many sandy beaches are in bad condition due to inappropriate exploitation, surrounding landscape destruction and degradation of the environment quality. In addition, some beaches are eroded even in risk of disappearing in the context of global sea level rise. For this reason, a comprehensive assessment of beach quality in all aspects of recreational, ecological and protective function will be scientific basis for utilization and management of the sandy beach in the routine of the integrated coastal management approach for the sustainable development.

\section{MATERIALS AND METHODS}

\section{Materials}

This study used data, results from projects that were carried out by the Institute of Marine Environment and Resources. They include: 1) The project: Study on the potential of development, innovation and protection of typical beaches in the Cat Ba tourist area (Hai Phong); 2) The project coded VAST 06.02/12-13: Study, evaluation and proposal on solutions for reasonable utilization and promotion of the value of the sandy beaches in Northeastern coastal area; 3) Results from the project of monitoring and analyzing the marine environment in the coastal area of the North of Vietnam from 2013 to 2015; 4) Supplementary data that were carried out by the authors during 2014.

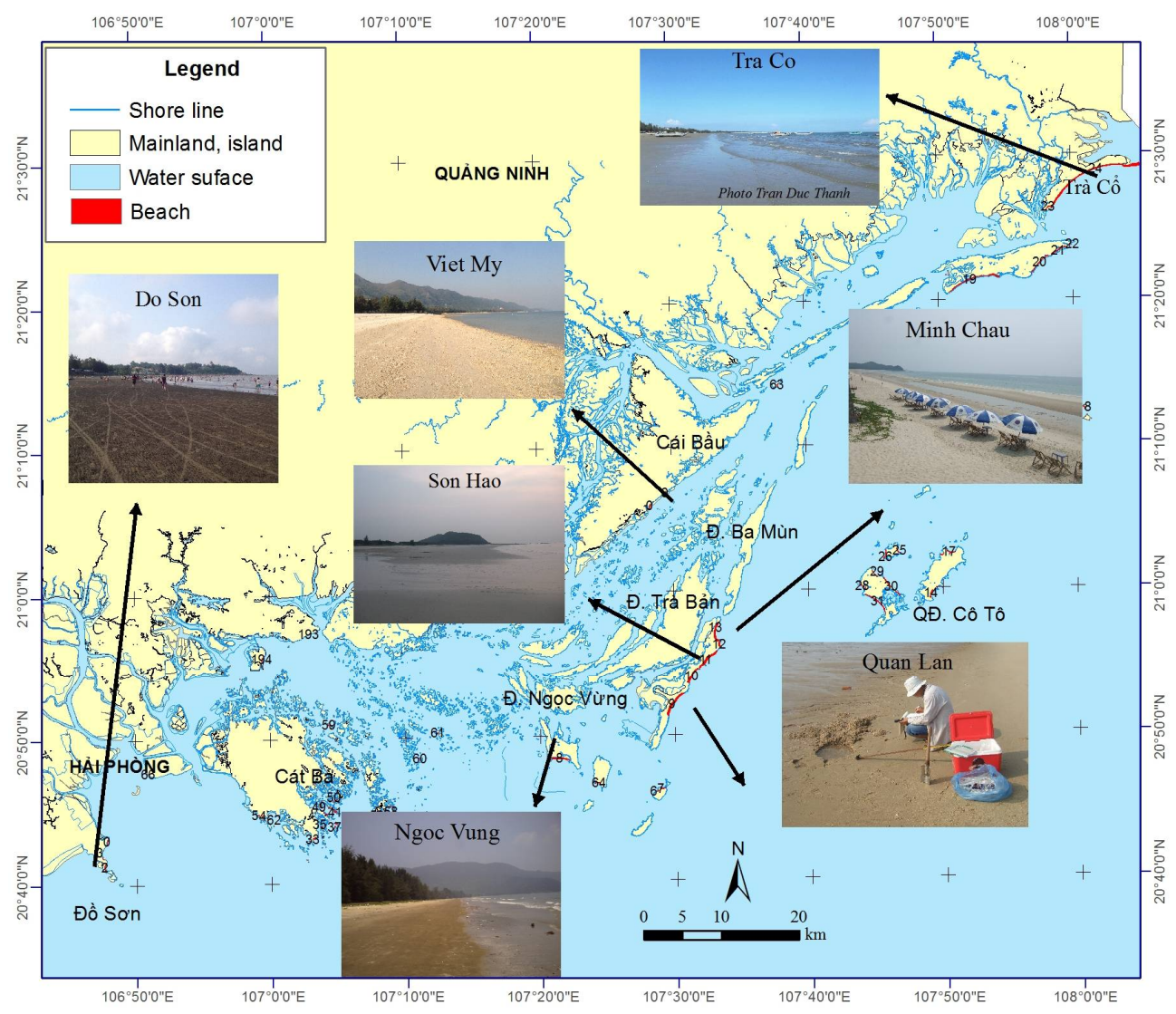

Fig. 1. Location of studied beaches 
Studied cases: 9 sandy beaches in the Northeastern coastal area were assessed. They are Tra Co, Do Son 1, Viet My, Son Hao, Minh Chau, Quan Lan, Ngoc Vung, Cat Co 1 (fig. 1). Beaches were selected based on their representative features of geographic distribution (mainland coast or island coast); typical beach materials (quartz or carbonate); and mode of beach usage and exploitation (public or private beach).

\section{Methods}

An effective method supporting management of the marine environment in general and of beach environment in particular is establishing set of indicator, index or criteria for assessing its quality [7-9]. One of the most popular indices is BQI (Beach Quality Index) first proposed by Eduard Ariza et al., and applied in many beaches all over the world (Europe, Chile, Taiwan, Australia...). At present, it has been an effective method for assisting in the management of the beach quality since it is the only index that integratedly assesses three functions of the sandy beach (recreational, ecological and protective function) [12]. The BQI was combined from 3 component indices: index of recreational function (RI), index of ecological function (NI) and the index of protective function (PI) (see equation 1).

$$
\mathrm{BQI}=\mathrm{p} 1(\mathrm{RI})+\mathrm{p} 2(\mathrm{NI})+\mathrm{p} 3(\mathrm{PI})
$$

Where: RI: Index of recreational function of the sandy beach; NI: Index of ecological function; PI: Index of protective function; p1, p2, p3: Weight of correspondent index.

BQI ranges from 0 to 1 , corresponding to the low to high quality of the sandy beach.

Each component index is a weighted combination of specific indices of the system. In this system, the component index, sub-index, and criteria were selected base on the following principle: Selecting inherit indices, indicators from similar researches in the world and in Vietnam [8, 10, 12, 13] and adjusting them in order to be suitable to the real condition of the study area as well as available collected data for assessing. The structure of BQI is shown in table 1 .
Table 1. The weight of component index and sub-index

\begin{tabular}{lrrrrr}
\hline & \multicolumn{1}{c}{$\begin{array}{l}\text { Total } \\
\text { coliform }\end{array}$} & & \multicolumn{1}{l}{$\begin{array}{l}\text { Faecal } \\
\text { coliform }\end{array}$} & & C value \\
\cline { 5 - 6 } \cline { 5 - 6 } \cline { 5 - 6 } Very good & 500 & & 100 & & 1 \\
Good & 2,000 & & 500 & & 0.8 \\
Moderate & 10,000 & & 2,000 & & 0.5 \\
Deficient & 100,000 & & 20,000 & & 0 \\
Bad & $>100,000$ & & 20,000 & & 0 \\
\hline
\end{tabular}

(According to Eduard Azira et al., 2010 [12]).

$\mathrm{RI}$ component is a weighted combination of sub-index of microbiological water quality (C), index of environment quality, index of service and facility, beach structure and morphology (table 1). In which, microbiological water quality has a great effect on the RI component.

$$
\mathrm{RI}=\mathrm{C} * \Sigma\left(\mathrm{Wi}_{\mathrm{r}} * \mathrm{Ii}_{\mathrm{r}}\right)
$$

Where: C- sub-index score of microbiological water quality and $\mathrm{C}$ is assigned value as described in table 1 ; $\mathrm{Ii}_{\mathrm{r}^{-}}$sub indice of $\mathrm{RI}$; $\mathrm{Wi}_{\mathrm{r}^{-}}$ weight of correspondent sub-index.

NI is a weighted combination of subindices of surrounding landscape, marine ecosystem habitat function (table 1).

$$
\mathrm{NI}=\Sigma\left(\mathrm{Wi}_{\mathrm{e}} * \mathrm{Ii}_{\mathrm{e}}\right)
$$

Where: $\mathrm{Ii}_{\mathrm{e}}$ : Sub-index of NI; $\mathrm{Wi}_{\mathrm{e}}$ : Weight of correspondent sub-index.

The protection index represents the role of beach in coastal protection and its features in the study area $[12,14]$. It includes a single subindex that measures a beach's capacity to dissipate wave energy and prevent damage to the promenades and maritime properties. The indicators included are the effective beach width (EBW), which is the distance between existing infrastructures and the shoreline; the storm reach (SR), which is the beach width potentially eroded by a storm of a given return period; and the minimum beach width (MBW), which is the minimum width of an operative beach required for protection purposes [14]. The MBW was assigned $20 \mathrm{~m}$ which is the minimum width of a good quality beach on the aspect of criteria of structure and morphology. Due to lack of information, SR was $13 \mathrm{~m}$ according to the result of Larson M. Kraus NC 
[15]. The PI would be calculated by the following equation:

$$
\mathrm{PI}=\mathrm{L}\left(\mathrm{IPP}_{1}>1\right) / \mathrm{LT}
$$

Where: PI- protection index; $\mathrm{IPP}_{1^{-}}$partial protective index (for a particular point of the beach) and $\mathrm{IPP}_{1}=\mathrm{EBW} /(\mathrm{SR}+\mathrm{MBW}) ; \mathrm{L}$ $\left(\operatorname{IPP}_{1}>1\right)-$ the total beach length in which the value of IPP is 1 or higher; LT- total length of the beach.
Defining the weight of component index and sub-index is an important step in the calculation of BQI. The weight was calculated according to the Saaty's nine-point pairwise matrix by consulting 15 experts in coastal and marine environment field [13]. This weighting method was more preeminent than the others because of the more exact results [16].

Table 2. Structure of beach quality index

\begin{tabular}{|c|c|c|c|}
\hline \multirow{12}{*}{ 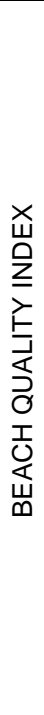 } & Component index & Sub-index & Criteria \\
\hline & \multirow{8}{*}{ Recreational index } & Microbiological water & - The concentration of total coliform \\
\hline & & quality & - The concentration of fecal coliform \\
\hline & & & - Oxygen demand \\
\hline & & & - TSS \\
\hline & & Environment quality & - Oil concentration \\
\hline & & & $\begin{array}{l}\text { - The presence of harmful organisms (poisonous } \\
\text { jelly-fish, teredo) }\end{array}$ \\
\hline & & Service and Facility & $\begin{array}{l}\text { Based on criteria of the Decision 2526/2013/QD- } \\
\text { UBND of the People Committee of Quang Ninh } \\
\text { Province issued on } 23 / 9 / 2013 \text { on the regulation of } \\
\text { beach in Quang Ninh }\end{array}$ \\
\hline & & $\begin{array}{l}\text { Beach structure and } \\
\text { morphology }\end{array}$ & $\begin{array}{l}\text { - Beach structure (width, slope, obstacle) } \\
\text { - Beach material (silica sand, carbonate sand) }\end{array}$ \\
\hline & & & - Surrounding landscape \\
\hline & Ecological index & $\begin{array}{l}\text { Characteristics of } \\
\text { ecosystem }\end{array}$ & $\begin{array}{l}\text { - Marine ecosystem (coral, seagrass) } \\
\text { - Habitat function (habitat, place for laying egg of } \\
\text { valuable animals) }\end{array}$ \\
\hline & Protection index & $\begin{array}{l}\text { Protection capacity of the } \\
\text { beach }\end{array}$ & $\begin{array}{l}\text { - Total length of the beach } \\
\text { - The effective beach width (EBW) }\end{array}$ \\
\hline
\end{tabular}

The score of criteria was assigned from 1 to 3 , corresponding to the low to high quality of beach.

\section{RESULTS}

\section{The weight}

Table 3 represented the average values of weight of component index and sub-index by using nine-point pairwise matrix.

Table 3. Weight of the component index and sub-index

\begin{tabular}{|c|c|c|c|}
\hline Component index & Weight & Sub-index & Weight \\
\hline & & Environment quality & 0.27 \\
\hline \multirow[t]{2}{*}{ Recreational function } & 0.45 & Service and Facility & 0.13 \\
\hline & & Beach structure and morphology & 0.05 \\
\hline Ecological function & 0.25 & Characteristics of ecosystem & 0.25 \\
\hline Protection function & 0.30 & Protection capacity of the beach & 0.3 \\
\hline
\end{tabular}

\section{The score of criteria}

\section{For the environment quality sub-index}

The criteria forming the environmental quality sub-index were selected based on the National Technical Regulation on Coastal Water Quality (QCVN 10:2008/BTNMT). Selected parameters include: TSS, Oil, DO, $\mathrm{COD}, \mathrm{NH}_{4}^{+}$. 
The level of beach quality on the aspect of environment quality was classified based on the category of water pollution according to the Circular No.17/2011/TT-BTNMT issued by the Ministry of Natural Resources and
Environment. According to that, the beach quality will be divided in 3 level: high, medium and low, corresponding to the scrore of 3,2 and 1 respectively (table 4 ).

Table 4. Criteria for scoring the sub-index of environmental quality

\begin{tabular}{|c|c|c|c|}
\hline \multirow{2}{*}{ Criteria } & \multicolumn{3}{|c|}{ Beach quality (score) } \\
\hline & Good (3) & Regular (2) & $\mathrm{Bad}(1)$ \\
\hline TSS (mg/l) & $<50$ & $50-150$ & $>150$ \\
\hline $\mathrm{DO}(\mathrm{mg} / \mathrm{l})$ & $\geq 4$ & $1.34-4$ & $<1.34$ \\
\hline COD (KMnO4) (mg/l) & $<4$ & $4-12$ & $>12$ \\
\hline Amoni $\left(\mathrm{NH}^{+}\right)(\mathrm{mg} / \mathrm{l})$ & $<0.5$ & $0.5-1.5$ & $>1.5$ \\
\hline Oil (mg/l) & $<0.1$ & $0.1-0.3$ & $>0.3$ \\
\hline
\end{tabular}

\section{Service and Facility}

The criteria of the sub index of service and facility were selected according to the results of E. Azira et al., (2010) and based on the
Decision 2526/2013/QD-UBND of Quang Ninh People Committee on the regulation of beach in Quang Ninh. They are described in table 5 .

Table 5. Criteria for scoring the sub-index of Service and Facility

\begin{tabular}{|c|c|c|c|}
\hline Criteria & Good (3) & Regular (2) & Bad (1) \\
\hline $\begin{array}{l}\text { Showers and feet } \\
\text { washers }\end{array}$ & $\begin{array}{l}\text { Distance between } \\
\text { showers/feet washers less } \\
\text { than } 150 \mathrm{~m}\end{array}$ & $\begin{array}{l}\text { Distance between } \\
\text { showers/feet washers from } \\
150-200 \mathrm{~m}\end{array}$ & $\begin{array}{l}\text { Distance between } \\
\text { showers/feet washer more } \\
\text { than } 200 \mathrm{~m}\end{array}$ \\
\hline $\begin{array}{l}\text { Bins and litter collected } \\
\text { system }\end{array}$ & $\begin{array}{l}\text { Distance between bins less } \\
\text { than } 50 \mathrm{~m}\end{array}$ & $\begin{array}{l}\text { Distance between bins } \\
\text { from } 50-100 \mathrm{~m}\end{array}$ & $\begin{array}{l}\text { Distance between bins more } \\
\text { than } 50 \mathrm{~m}\end{array}$ \\
\hline $\begin{array}{l}\text { There are buoys, flags, } \\
\text { signs of safety corridors }\end{array}$ & Yes & Sparse & None \\
\hline Rescue stations & $\begin{array}{l}\text { Distance between stations } \\
\text { less than } 300 \mathrm{~m}\end{array}$ & $\begin{array}{l}\text { Distance between stations } \\
\text { is } 300 \mathrm{~m}\end{array}$ & $\begin{array}{l}\text { None or distance between } \\
\text { stations more than } 300 \mathrm{~m}\end{array}$ \\
\hline
\end{tabular}

(According to E. Azira et al., (2010) and Decision 2526/2013/QD-UBND of Quang Ninh People Committee).

\section{Beach structure}

Beach structure and morphology such as slope, width, materials have a significant effect on beach attraction. A large but narrow sandy beach (width not exceeding $20 \mathrm{~m}$ ) or beach slope greater than 0.025 , or complex grade of sand is not assessed as high quality. The beach structure is closely related to particle size and reflects the morphodynamic characteristics of the beach. Steep and narrow beach surfaces are found in the high energy shoreline and its materials consist of coarser particles (medium, coarse sand, and calcareous-pieces) and have sigfinicant change by season (unstable). Those beaches can not have high quality. The slope of 0.005 is considered the critical one for development of sand bar [17]. That means the minimum slope of beach is 0.005 but in practice, it is usually higher and can reach 0.05 for the beach of coarse and very coarse materials. Thus, beach is dissipative when its slope is less than 0.01 and reflective when its slope is more than 0.25 . In the case of beach with complex grade of sand, its slope is mean value that is calculated from the centre of beach.

The grain size is a major factor for assessment of beach quality. The smoothness of beach materials is a significant factor for a high quality. Normally, a sandy beach of good quality has grain size ranging from $0.25-0.5 \mathrm{~mm}$. Beaches which are constituted from the sand with Md ranging from $0.1-0.25$ or 0.25 - 
$0.5 \mathrm{~mm}$, are considered as medium quality. Low quality is assigned to a beach which is composed of very fine sand ( $\mathrm{Md}$ in the range of 0.05 $0.10 \mathrm{~mm})$ or very coarse sand $(\mathrm{Md}>1)$.

Table 6. Criteria for scoring the sub-index of structure and morphology

\begin{tabular}{|c|c|c|c|c|}
\hline \multirow{2}{*}{ Sub-index } & \multirow{2}{*}{ Criteria } & \multicolumn{3}{|c|}{ Quality level } \\
\hline & & High (3) & Medium (2) & Low \\
\hline \multirow{4}{*}{$\begin{array}{l}\text { Structure } \\
\text { and } \\
\text { morphology }\end{array}$} & Beach width & $\begin{array}{l}\text { Beach surface is } \\
\text { dissipative and more } \\
\text { than } 30 \mathrm{~m} \text { wide }\end{array}$ & $\begin{array}{l}\text { - Beach surface is rather } \\
\text { dissipative beach and its width } \\
\text { ranges } 20-30 \mathrm{~m} \text { or. } \\
\text { - Beach surface is reflective } \\
\text { and more than } 30 \mathrm{~m} \text { wide }\end{array}$ & \multirow[t]{2}{*}{$\begin{array}{l}\text { - Beach surface is not very } \\
\text { dissipative and less than } \\
20 \mathrm{~m} \text { wide or. } \\
\text { - Beach surface is reflective } \\
\text { and less than } 30 \mathrm{~m} \text { wide } \\
>0.025\end{array}$} \\
\hline & Medium slope & $<0.01$ & $0.01-0.025$ & \\
\hline & Grain size $(M d)$ & $0.25-0.5 \mathrm{~mm}$ & $0.1-0.25 \mathrm{~mm}$ or $0.5-1.0 \mathrm{~mm}$ & \multirow{2}{*}{$0.05-0.1 \mathrm{~mm}$ or $\mathrm{Md}>1.0 \mathrm{~mm}$} \\
\hline & Grain colour & White, yellow & Brown & \\
\hline
\end{tabular}

\section{Index of ecological function of sandy beaches}

3 criteria were selected by assessing the biological feature of the sandy beaches in the Northeastern coastal area of Vietnam. They include the surrounding landscape, enclosed marine habitat, and habitat function (habitat, place for egg laying of valuable animals). They are all important functions of the sandy beaches in the study area (table 7).

Table 7. Criteria for scoring the ecological index

\begin{tabular}{|c|c|c|c|c|}
\hline \multirow{2}{*}{$\begin{array}{l}\text { Component } \\
\text { index }\end{array}$} & \multirow{2}{*}{ Criteria } & \multicolumn{3}{|c|}{ Quality level } \\
\hline & & High (3) & Medium (2) & Low (1) \\
\hline \multirow{3}{*}{$\begin{array}{l}\text { Ecological } \\
\text { function }\end{array}$} & Surrounding landscape & $\begin{array}{l}\text { There is a } \\
\text { natural forest } \\
\text { behind beach }\end{array}$ & $\begin{array}{l}\text { There is a sparse natural } \\
\text { forest, or plantation forest or } \\
\text { tourist area behind the } \\
\text { beach. }\end{array}$ & $\begin{array}{l}\text { There is a very sparse natural } \\
\text { forest, or residential area, } \\
\text { industrial area, aquaculture } \\
\text { area. }\end{array}$ \\
\hline & $\begin{array}{l}\text { Presence of typical } \\
\text { ecosystem }\end{array}$ & Typical & Untypical & None \\
\hline & $\begin{array}{l}\text { Other ecological } \\
\text { functions: a place for } \\
\text { egg laying of sea } \\
\text { turtles, a place for } \\
\text { marine birds of prey. }\end{array}$ & Typical & Untypical & None \\
\hline
\end{tabular}

\section{Protection index}

Satellite images of SPOT 4 archieved in 2008, LANDSAT 8 in 2013, ALOS AVERNIR 2 in 2010 were used to calculate the length and width of beaches. The protection index of beaches was calculcated and described in figure 8. In which, Tra Co, Quan Lan, Son Ha, Ngoc Vung, Minh Chau, Cat Ba have maximum value of protection index. The others have value ranging from 0.65 to 0.97 .

\section{Result of integrated assessment of sandy beach quality}

Most of the whose quality index was assessed are recreational beaches. Some are used both for recreation and boat parking (Tra Co beach). Because of the local weather's characteristics, beaches are only used in the summer (from May to September). The field survey data from 2013 to 2014 in the study area were collected and used for BQI calculation. Results of criteria calculation were normalized in the scale of 0 to 1 . Component, sub-index were combinationlly weighted by the equations (1), (2), (3).

Table 8 presents the result of BQI and its components calculated for the 9 sandy beaches. BQI results ranged from 0.36 to 0.71 . Most of the beaches obtained the BQI in the scale of good or rather good quality. While Do Son 1 
Do Thi Thu Huong, Nguyen Dinh Hoe,...

beach had the lowest BQI value with 0.36, highest BQI.

Minh Chau and Son Hao beaches got the

Table 8. The BQI of the beaches in the study area

\begin{tabular}{|c|c|c|c|c|c|c|}
\hline Beach & $\begin{array}{c}\text { Beach } \\
\text { length }(m)\end{array}$ & Width(m) & $\begin{array}{l}\text { Recreational } \\
\text { index }\end{array}$ & $\begin{array}{l}\text { Ecological } \\
\text { index }\end{array}$ & $\begin{array}{l}\text { Protection } \\
\text { index }\end{array}$ & BQI \\
\hline Tra Co & 13,000 & 100 & 0.6 & 0.17 & 1.00 & 0.61 \\
\hline Quan Lan & 3,500 & 32 & 0.5 & 0.67 & 1.00 & 0.67 \\
\hline Son Hao & 2,280 & 40 & 0.6 & 0.50 & 1.00 & 0.70 \\
\hline Minh Chau & 2,760 & 35 & 0.5 & 0.83 & 0.97 & 0.71 \\
\hline Ngoc Vung & 2,290 & 25 & 0.5 & 0.67 & 1.00 & 0.67 \\
\hline Cat Co 1 & 163 & 40 & 0.3 & 0.50 & 1.00 & 0.56 \\
\hline Do Son 1 & 550 & 35 & 0.3 & 0.17 & 0.65 & 0.36 \\
\hline Bai Dai & 100 & 33 & 0.6 & 0.17 & 0.84 & 0.56 \\
\hline Viet My 1 & 408 & 50 & 0.6 & 0.17 & 0.86 & 0.56 \\
\hline
\end{tabular}

The score of the microbiological sub-index of water quality was high in almost all the beaches except Do Son 1 and Cat Co 1 . Meanwhile, the score of water quality subindex in most beaches archived good level $(>0.5)$, except Do Son 1 beach was in the bad quality level (figure 2). It can be seen that all intensely used beaches such as Cat Ba, Do Son,
Tra Co... had lower score of sub-index than island beaches. The score of sub-index of service and facility was rather low for almost all the beaches in the study area. By contrast, the sub-index of structure and morphology was high in all the beaches since they fulfilled all requirements of beach width, slope and grain for a high quality of beaches.

The score of sub-index

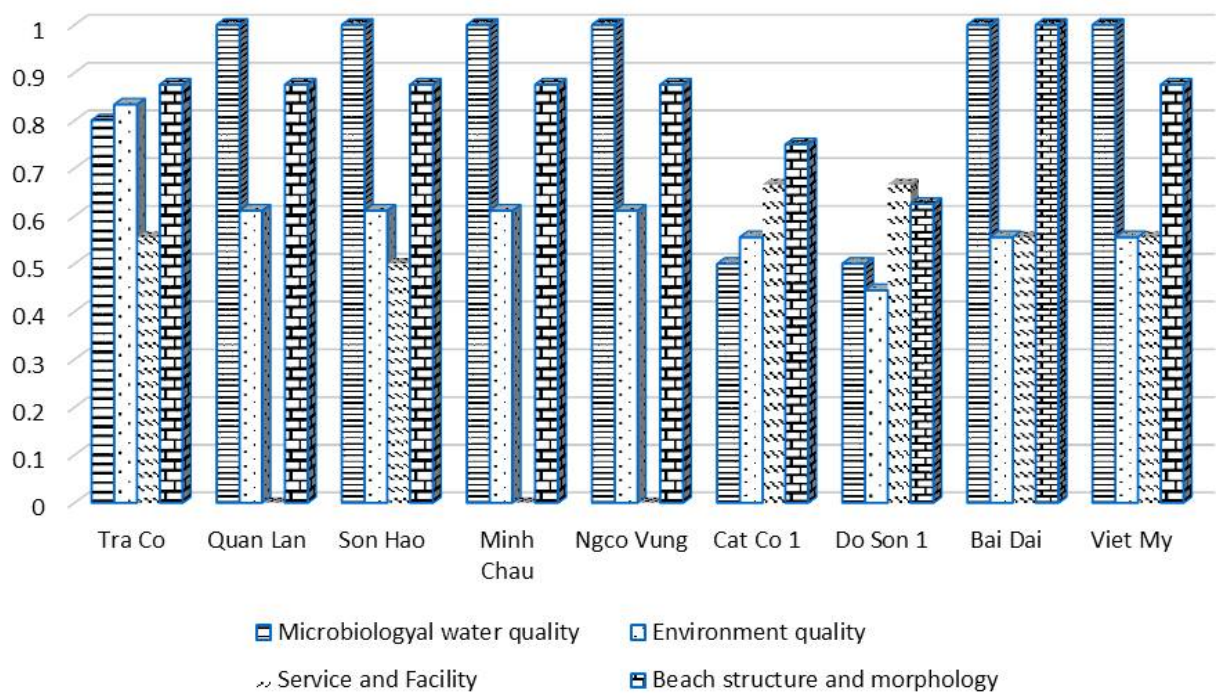

Fig. 2. Score of sub-indices

\section{DISCUSSION}

Assessment of sandy beach quality by using BQI gave us a comprehensive result on the beach's function. The obtained results revealed state of beach quality in the Northeastern coast of Vietnam. The beach quality in the study area varied from poor to 
good level. It can be seen that the beaches near mainland coast have quality lower than the island beaches. Those are resulted from the difference in environmental features, materials and morphological characteristics of the beaches. In addition, the mainland coastal beaches are affected by pollution sources from human activities much more than the island beaches. Moreover, for the beaches that are used for recreation for long time, the landscape behind beaches is not original, and converted into infrastructure or entertainment areas. That state also results in lower value of score of ecological function index.

The comparion of the scores of component indices show that most of the beaches have high value of recreational and protection index while ecological index obtains lower value. For the recreational index, Bai Dai and Viet My have the highest score because they meet all requirements about infrastructure, water quality and sediment for a good quality beach. However, they also have some obstacles such as: a large amount of shell and sea goblin is on these beaches and can harm beach users. About the ecological function index, Minh Chau, Quan Lan, Ngoc Vung beaches have highest score as there are valuable marine ecosystems in the surrounding areas of beaches. The remains receive lower score since the landscape behind beaches is destroyed by development activities such as: construction, sand exploitation on dune... The score of protection index is high for most of the beaches owing to their large surface width. In addition, they are located in bay condition with island barrier, so the impacts of wave and wind reduce significantly when reaching the beaches.

In comparison with BQI results of beaches in Chile, Spain that were published previously, the quality of sandy beach in the Northeast of Vietnam is lower than in Spain [12] but higher than in Chile [18]. Thus, BQI allows comparing the quality between beaches regardless of geographic distance, even when its sub-indices or criteria adapt to local conditions. In addition, analysis of its components, sub-indices let users identify the strong and weak aspects of the sandy beaches and since then give solutions for improving environmental quality of the beaches.

The limitation of this study was using score of protection index referenced from results of other researches abroad due to lack of data to calculate the local score. Although referenced score of protection index was used for calculating BQI of many beaches in the world, this may affect the final result due to disparity of local characteristics.

\section{CONCLUSION}

BQI enables us to assess the beach quality in the Northeastern Vietnam via new and comprehensive approach since it not only evaluates the environmental quality of beaches but also assesses the beach's capacity in satisfying tourism demand as well as its protection function. Moreover, the BQI enables the users to recognize strong, weak points of sandy beaches, identify environmental aspects which need to be improved, monitor effectively the management programs. Since then, the rational solution can be developed in order to improve beach quality toward sustainable use of the beach.

The results of BQI calculation in some pilot beaches in the Northeastern area of Vietnam show that Quan Lan, Minh Chau, Son Hao and Ngoc Vung beaches achieve high level of quality (BQI>0.65), Tra Co, Cat Co 1, Bai Dai, Viet My 1 have medium quality (BQI from 0.5 to 0.65$)$, Do Son 1 beach obtains bad quality $(\mathrm{BQI}=0.36)$. Analysis of the sub-indices indicates that the sandy beaches in the Northeastern of Vietnam have high value of the structure index and low value of the water quality and infrastructure and service index. This result also reflects the status of arbitrary use of resources and lack of synchronous management of the sandy beaches of Northeastern Vietnam.

\section{REFERENCES}

1. Botero, C. M., Pereira, C., Anfuso, G., Cervantes, O., Williams, A. T., Pranzini, E., and Silva, C. P., 2014. Recreational parameters as an assessment tool for beach quality. Journal of Coastal Research, 70(sp1), 556-562. 
2. Houston, J. R., 2002. The economic value of beaches-a 2002 update. Shore and Beach, 70(1), 9-12.

3. Laws, E., 1995. Tourist destination management: issues, analysis and policies. Routledge. Routledge, New York. 10001. 1995. $208 \mathrm{p}$.

4. Williams, A. T., Pond, K., Ergin, A., and Cullis, M. J., 2013. The hazards of beach litter. In Coastal Hazards (pp. 753-780). Springer Netherlands.

5. Jang, Y. C., Hong, S., Lee, J., Lee, M. J., and Shim, W. J., 2014. Estimation of lost tourism revenue in Geoje island from the 2011 marine debris pollution event in South Korea. Marine Pollution Bulletin, 81(1), 49-54.

6. Lozoya, J. P., Sardá, R., and Jiménez, J. A., 2014. Users expectations and the need for differential beach management frameworks along the Costa Brava: Urban vs. natural protected beaches. Land Use Policy, 38, 397-414.

7. Nguyen Dinh Hoe and Vu Van Hieu, 2007. Systematic approach in environmental research and development. VNU Press.

8. Tran Dinh Lan, 2007. Study on the rational use of natural resources of the coastal areas in the Northeast of Vietnam based on development of environment indicators. Doctoral Thesis on Geographic Science, Hanoi University of Science, Vietnam National University.

9. Do Thi Thu Huong, Tran Dinh Lan, 2009. An assessment of the change in mangrove area and quality in the Hai Phong coastal area using remote sensing data and GIS technology. Journal of Marine Science and Technology, 9(Supplement 1), 295-337.

10. Espejel, I., Espinoza-Tenorio, A., Cervantes, O., Popoca, I., Mejia, A., and Delhumeau, S., 2007. Proposal for an integrated risk index for the planning of recreational beaches: use at seven Mexican arid sites. Journal of Coastal Research. SI

\section{ICS2007 (Proceedings) Australia,} 47-51.

11. Do Thi Thu Huong, Nguyen Dac Ve, 2013. Inventory of sandy beaches in northeast Vietnam coastal areas using remotely sensed data. The Proceedings of the $2^{\text {rd }}$ National Symposium on Marine Geology, pp. 191-154.

12. Ariza, E., Jimenez, J. A., Sarda, R., Villares, M., Pinto, J., Fraguell, R., Roca, E., Marti, C., Valdemoro, H., Ballester, R., and Fluvia, M., 2010. Proposal for an integral quality index for urban and urbanized beaches. Environmental Management, 45(5), 998-1013.

13. Cervantes, O., and Espejel, I., 2008. Design of an integrated evaluation index for recreational beaches. Ocean \& Coastal Management, 51(5), 410-419.

14. Valdemoro, H. I., and Jiménez, J. A., 2006. The influence of shoreline dynamics on the use and exploitation of Mediterranean tourist beaches. Coastal Management, 34(4), 405-423.

15. Larson, M., and Kraus, N. C., 1989. SBEACH: numerical model for simulating storm-induced beach change. Report 1. Empirical foundation and model development (No. CERC-TR-89-9). Coastal Engineering Research Center Vicksburg Ms.

16. Selection Method for Calculating Weights to Determine Flood Vulnerability Index in Vu Gia - Thu Bon basin. VNU Journal of Science: Natural Science and Technology, 31(1S), 93-102.

17. Zenkovich, V. P., 1962. Some new exploration results about sand shores development during the sea transgression. NVA Oosthoek, pp. 113-121

18. González, S. A., and Holtmann-Ahumada, G., 2017. Quality of tourist beaches of northern Chile: A first approach for ecosystem-based management. Ocean \& Coastal Management, 137, 154-164. 